\title{
The Philanthropy Culture in the Local Area: The Role Study of Philanthropy Institution after the Termination of PNPM in Boyolali Regency
}

\author{
Putut Suharso ${ }^{1,2^{*}}$, Sarbini Sarbini ${ }^{3}$, dan Dicky Sumarsono ${ }^{2}$ \\ ${ }^{1}$ Department of Library and Information Science, Diponegoro University, Prof. H. Soedarto SH \\ Street, Semarang 50275 Indonesia \\ ${ }^{2}$ Postgraduate Program in Cultural Studies, Sebelas Maret University, Ir. Sutarmi 36A Street, \\ Surakarta 57126, Indonesia \\ ${ }^{3}$ Communication of Islamic Broadcasting, Faculty of Ushuludin and Da'wah - IAIN Surakarta, \\ Pandawa Street, Pucangan, Kartasura, Sukoharjo 57168, Indonesia
}

\begin{abstract}
The development of paradigm prioritizes more on the economic development by maintaining social structure. The state takes an intervention role with several social programs to solve social issues. On the other hand, the charity tradition is one of the important aspects in life including the doctrine of every religion. The purpose of this research is to observe the Indonesian people who still own the charity tradition came from their religious tradition Islam teaches charity through zakat, infak, shadaqah and wakaf (ZISWAF) which has existed in the society as the symbol of the social piety. This research uses sociological approach and qualitative method while the method of collecting data uses observation, interview and study of documentation. As for the analysis, the analysis of descriptive qualitative uses the theory of Social Justice Philanthropy in charity tradition as the spontaneous action of human if they see another human is treated unfairly by state or more authorized person. The results of the research are: first, the philanthropy institution is oriented on destitute family which is unfinished handled by the state through PNPM program in charity social service because the target of the program is destitute group so it has not finished yet. Second, the philanthropy institution on its movement is built in the name of religious spirit capitalized into Social Justice Philanthropy. Third, the philanthropy institution in the empowerment of destitute society is followed by mastery which does not only focus on charity, capacity but also on authority by creating destitute family must be an entrepreneur.
\end{abstract}

\footnotetext{
${ }^{*}$ Corresponding author:putut.undip@gmail.com
} 


\section{Introduction}

The state's failure in realizing the prosperity equity is the impact of the policy's orientation which is more side with the market needs. The development of paradigm gives more priorities to the economic growth by maintaining unstable social structure. The social issues occur as the consequences of the alienaton of some societies from the economic growth. Referring to the Oscar Lewis theory that those who are eliminated remain struggling in the model of subsistence economy which relies on the remained opportunities in economic which is on the other side the modern economic remains working with high efficiency [1]. The state of Indonesia takes an intervention role by holding several social programs to solve some social issues such as Program Nasional Pemberdayaan Masyarakat (PNPM), Program Keluarga Harapan (PKH), Dana Penanganan Bencana Operasional (DPBO), Biaya Operasional Sekolah (BOS), Jaminan Kesehatan Masyarakat $(J K M)$ and other programs.

Besides, the charity tradition (philanthropy) is one of the important aspects in the social creature living, even in religious doctrine obligates the worshippers to give[2]. Most of Indonesian people whorsip a religion which has charity tradition from the ancient tradition. Even in Java, there is Kondangan tradition as a charity tradition. Islam teaches charity through zakat, infak, shadaqah and wakaf (ZISWAF) which has existed in society as the symbol of social piety. This tradition was born with various complex motives as the expression of a relationship between both charity givers and recipients[3]. The born of philanthropy institution encourages the development of charity culture into philanthropism tradition. One of those which is growing is Islamic philanthropy through the potential accumulation of ZISWAF. A lot of philanthropy institutions are the actual responses of the organizers in facing social issues of which are considered handled by the state in giving welfare to the most marginal society group.

This condition encourages the society's involvement in the form of collective social action. The social action is covered by various movements to respond various social, economic and political issue. There are 3 variation of society's respond in seeing the state's limitation to solve the society's prosperity. In the context of civil society in Boyolali, it can be mapped as follows; the first is service-oriented organization. This organization provides help and short term assistance such as done by mosques and society organization (Muhammadiyah, NU, MTA, LDII). The second is development-oriented organization. This organization tries to develop the society outside the government's structure. The organization tries to raise the collective involvement of people to directly join the eradication of social issues in micro level (individual and community), such as providing micro credit, assisting business and providing access of education and health. This role is played by one of the modern philanthropy organizations. The third is movement-oriented organization. The organization conducts the efforts of collective awareness to pursue the structure changing of social, economy, and politic such as the movement of university's students, $L S M$, foundation and another organization of civil society.

From the explanation above, it shows that philanthropy institution has a strategic role to overcome the poverty both through activities and movement which are either implemented in empowerment or policy related to the authority owned. Therefore, the research of Islamic philanthropy utilization towards the empowerment of destitute society is attracted the researchers' interest. Boyolali Regency is chosen as the research area because there is various view of different orientation in responding poverty both understanding the concept of poverties, roles, activities and the involvement of philanthropy institution in solving the poverty. The main problem which will be answered in this research is "How is the role of philanthropy institution (Lazismu, Lazisnu and Baznas) in Boyolali Regency in empowering destitute society?" 
The concept of philanthropy for social justice becomes the bridge between the rich and the poor. The bridge is realized in the effort to mobilize the source in giving service to the poor[4]. Truthfully, there are two concepts of philanthropy: (1) The volunteerism which is not able to be demanded by the giver, (2) Philanthropy is a transitional mean of source from the richer to the poorer. The philanthropy concept of social justice is a development of philanthropy concept as the organized charity practice to solve various injustice issues in society. It is different from the practical philanthropy with Karitatif approach which emphasizes on the compensation and social service. This concept focuses more on the effort to solve the main issue of injustice social not the symptoms. The charity is prioritized more to support strategic and long term programs in solving the issues of injustice social. The efforts are supporting and funding the policy of advocacy, assisting law, enforcing the human right, empowering women, protecting children, preserving the environment and etc. Barry Knight [5] formulates five programs which can be included into SJP, they are; (1) The fulfillment of main daily needs; (2) the redistribution of power; (3) the transformation of values to develop the plurality and diversity; (4) the increase of community capacity; (5) the public participation in deciding a decision. SJPhas a fairly wide range of intervention starting from providing social service to establishing the movement in solving the main issue. The issues included in SJPdo not only concern to the civil and political rights but also economics, social and cultural rights.

According to James O. Midgley [6], the concept of SJPin the third sector (not state or private) as a prosperity provider has 4 categories; First, non-formal service which is ran in the name of cultural obligation through family, relative, friendship, neighbor, and network community. Second, service ran in the basis of cultural obligation of religious-based because its orientations are based on religious doctrines, one of those is giving (zakat). Third, the prosperity system is ran by cooperative association such as cooperative, regular social gathering (arisan), and the revolved loan in group. Fourth, the prosperity system is run collectively to develop the prosperity together such as holding a business communally. The existence of the third sector is manifested in various ways to give social services. While, Michael Hill [7] states that the prosperity service provider for society is divided into four factors; first, the social services are given by the state through its various social policies. Second, the social services given by market through private business which encourages the economic turnover included giving job vacancies. Third, social services are given by a family. Fourth, social services are given by third sector institution such as volunteer (community, volunteer, and autonomy institution of government) in the form of non-profitable organization such as BAZNAS (Badan Amil Zakat Nasional), LAZISMU, LAZISNU. Household and volunteer are two sectors which can be categorized as in third sector as civil society, in this context of the research is philanthropy institution which takes a role as the provider of prosperity in society besides the state and market. The existence of third sector as the alternative is a contact from three sectors; state, market and community. The existence of third sector becomes the bridge among the three in exploring resource from the three which completes every role. To realize the role of third sector, Midgley describes three strategies/approaches in increasing the society's prosperity[6] through individual approach, society approach and based on state role.

Table 1. The typology classification of informal institution in creating prosperity by civil society

\begin{tabular}{|l|c|c|}
\hline & FORMAL & INFORMAL \\
\hline Compatible goals & Complementary & Substitutive \\
\hline Conflicting goals & Accommodating & Competiting \\
\hline
\end{tabular}


Helmke and Levitsky [8] build the relation of typology between both formal and informal sector by using two dimensions, the first is the effectiveness from formal sector and the second is the position of purposes between both formal and informal sector. This approach forms four patterns of informal sector relation (third sector) and formal sector (state and market) like complementary, substitutive, accommodating and completing. Observing the position of informal sector and formal sector will be determined by two things, the first is the achieved purpose by both formal and informal sector, if both of them are in the same position so they can complete or substitute each other. This position is determined from the state's effectiveness in realizing prosperity. The three effective states will put the third sector of which the purpose as complementory, instead if the state does not run the function effectively so the third sector will arise automatically taking role as substitutive. The informal sector which position its purposes differ from the formal sector approach will arise the accommodation or competition

The three states are capable to run the function effectively. The existence of third sector will be accommodated as the alternative for the prosperity's service outside the state. The existence of third sector which is accommodated will oversee the society not to rely totally on the state. Instead, a state is not able to make the prosperity performance effective, so the third sector which has different orientation from the state's purpose will make the state as the competitor. The competition is articulated with the policy choice which is oriented to oversee the state's legitimacy in public in realizing the effort of limitation or regulation to ensure the third sector does not break the state's legitimacy.

The existence of social services to realize the third sector based of prosperity is a response of social, economy, and political condition. The third sector is the representation of society's solidarity which is realized in the redistribution of prosperity. The existence is influenced by the development of industrialization which caused new middle-class structure while leaving some of the society eliminated from the development. The inequality access encourages the solidarity of middle-class society to support the providing social service for destitute society. In the context of Islamic philanthropy in Indonesia, the social solidarity is realized in third sector institutions which are established due to the society's initiative.

\section{Materials and Methods}

The research tries to reveal the role of philanthropy institution (Lazismu, Lazisnu and Baznas) in fulfilling the state's limitation particularly in solving the poverty. The role meant is the social role which includes the behavior of individual, institution or society results in social norms which are able to determine hope in an interaction. In explaining the activities, motives and roles of philanthropy institution is used sociological approach to explain the social behavior which influences on the empowerment activities of destitute society.

The qualitative method is used to describe the social reality in empowering as the effort to overcome poverty. The collecting of the data is obtained through observation, profound interview, and document study (written), which is classified as primary data. Meanwhile, secondary data is additional information such as theories, historical information and other data which has function to complete the primary data. The secondary data is traced though literature studies with the information from the authorized institutions. In this research, the researcher directly explored the data and the information from the informants. The informants are consisted from the leader of Lazismu, Lazisnu and Baznas Boyolali with 5 people for each institution. This consideration is based on the characteristic of qualitative approach which demands the human work model[9,10]. 
In this analysis, the paradigm used is sociological paradigm from the whole aspects which has relationship with the society and the whole aspects resulted by society and the sociological study scope[11]. Whereas, the data analysis used the analysis of descriptive qualitative by explaining the social facts like behaviors, motives and activities of philanthropy institution in empowering the poverty solving in Boyolali which is understood as the social phenomena. Besides using, the method of descriptive qualitative, it is also using the analysis method of qualitative descriptive-interpretative. This method is used to find the role and the strategy of Ulama in the activities of empowerment the destitute society. It is in line with the purpose of using the analysis method of interpretative qualitative to find verstehen (understanding), so the analysis by relating the described data with the theory to explain the social facts occurred in order to formulate a generalization which refers to the theoretical preposition reflected the social reality.

\section{Results and Discussions}

\subsection{The State's Service Towards Destitute Society in Boyolali Through PNPM}

PNPM (Program Nasional Pemberdayaan Masyarakat) is a development progarm to overcome poverty which was originally from PPK (Program Pengembangan Kecamatan) and P2KP (Program Penanggulangan Kemiskinan Perkotaan). PNPM (PPK, P2KP) is the advanced program of poverty solving since 1994, IDT, PKT, P3DT, P4k, and etc. Since 2005, 42 programs of poverty solving have been conducted by 17 government institution both department and non-department which is harmonized and integrated in PNPM which functions to answer the basic issues from the society by providing employment for destitute society (solve the jobless issues) and add the income for destitute society group (poverty solving). The infrastructures both rural and urban become the main target which is expected to give bigger multiplier impact by lowering the cost of transaction and marketing so it allows wider business opportunity and lowers the living cost.

PNPM which has run since 2007 until 2014 has central fund about IDR 135 billion added with the regional assistance about IDR 8 billion which has been transferred from the central government to the local government for 7 years. During the program, the poverty condition can be shown in the data as follows:

Table 2. The number of Detitute Society in Boyolali 2010-2014

\begin{tabular}{|c|c|c|c|c|}
\hline No & Year & $\begin{array}{c}\text { The number } \\
\text { of society }\end{array}$ & $\begin{array}{c}\text { The number } \\
\text { of destitute } \\
\text { society }\end{array}$ & Percentage \\
\hline 1 & 2010 & 953.839 & 127.800 & 13.72 \\
\hline 2 & 2011 & 956.850 & 139.516 & 14.97 \\
\hline 3 & 2012 & 959.732 & 129.100 & 13.88 \\
\hline 4 & 2013 & 963.839 & 126.500 & 13.27 \\
\hline 5 & 2014 & 967.215 & 118.581 & 12.36 \\
\hline
\end{tabular}

Source: Central Bureau of Statistics, Boyolali

Although the poverty condition is quiet high (Table 2) in this context, but the impacts of PNPM in empowering the poverty society are as follows; (1) creating the atmosphere or 
climate which allows the development of potency or power owned by society to encourage the awareness. (2) The strong power owned by society through giving input such as funding, building facilities and amenities both physically (road, irrigation, electrical) and socially (school, health) as well as the development of funding institution for any opportunities which make the society more powerful. (3) The support to the weak society to prevent unstable competition due to the powerless in facing the strong one.

\subsection{The Poverty Condition after the Termination of PNPM}

In some studies conducted by Word Bank, PNPM can reduce the number of poverty in Indonesia and ensure the destitute society's participation to have freedom in deciding a decision[12]. However, a lot of faults of the program are found such as the affordability of PNPM doer, the model of communication, culture, religion and etc, which hampers the program which then played by the third doer (philanthropy institution) so that the activities of poverty solving stay running without PNPM program. The following is the poverty data in Boyolali after the termination of PNPM

Table 3. The number of destitute society in Boyolali 2015-2017

\begin{tabular}{|c|c|c|c|c|}
\hline No & Year & $\begin{array}{c}\text { The } \\
\text { number of } \\
\text { society }\end{array}$ & $\begin{array}{c}\text { The } \\
\text { number } \\
\text { of } \\
\text { destitute } \\
\text { society }\end{array}$ & Percentage \\
\hline 1 & 2015 & 971.245 & 119.970 & 12.45 \\
\hline 2 & 2016 & 974.741 & 117.000 & 12.09 \\
\hline 3 & 2017 & 974.579 & 116.390 & 11.96 \\
\hline
\end{tabular}

Source: Central Bureau of Statistics, Boyolali

According to the Head of Bappeda, there are 4 factors which influence on the decreasing number of poverty after the termination of PNPM (in table 3), the factors are; (1) the condition of economy both macro and micro in national, Central Java or Boyolali from the elements of $A P B N, A P B D$ which is led to the infrastructure, (2) the growth of social service insititution (philanthropy) in helping destitue society, (3) the existence of micro credit by financial institution based on non-governmental institution (the outing program of PNPM) followed with the growth of UMKM, (4) The development of agricultural and ranch sector facilitated by social service institution.

In the research, it is found the data about the role of philanthropy institutions both formal (Lazismu, Lazisnu, Baznas, Rumah Zakat, LAZ of Central Java, AITAM, Solo Peduli) and informal (Ta'mir Masjid, Majelis Taklim, groups) have a big contribution in solving the poverty in the level of grassroot. The philanthropy institutions take the state's role such giving the working capital, giving the working tools, giving medical treatment for sick people, giving scholarship and school supply, renovating houses, giving the seeds of agricultural plants and ets. This activities are targeting the destitute society and facilitating the household needs which become the big component of outcome household of destitute society in Boyolali Regency.

\subsection{The Formal Philanthropy Institution Involved in Social Service}


The philanthropy instituions mentioned above are Organisasi Pengelola Zakat (OPZ). There are 7 institutions noted in the Ministry of Religion in Boyolali in accordance with the Regulation Number 23 the Year 2011 on the Management of Zakat, there are only 5 institutions admitted; Baznas, Lazisnu, Lazismu, Rumah Zakat and Solo Peduli. Every OPZ has the different strategies of fundraising, management, fund distribution and supervision based on their own vission, mission, and target of OPZ. Baznas and Solo Peduli focus on the giving the capital of agriculture, ranch, and working for destitute family in distributing the programs. While Lazismu and Aitam focus on giving scholarship for destitute children, renovating house of destitute society, disaster management, and free medical treatment. Lazisnu focus on funding and work training. OPZ also has an tentative assistance activity.

Table 4. The Management of Institution

\begin{tabular}{|c|c|c|c|c|c|}
\hline No & $\begin{array}{c}\text { The institution } \\
\text { of } \text { Amil Zakat }\end{array}$ & $\begin{array}{c}\text { Legal entity } \\
\text { and } \\
\text { AD/ART }\end{array}$ & $\begin{array}{c}\text { Work } \\
\text { Program }\end{array}$ & $\begin{array}{c}\text { Annual } \\
\text { Meetings }\end{array}$ & $\begin{array}{c}\text { Socializat } \\
\text { ion }\end{array}$ \\
\hline 1 & BAZNAS & available & available & available & available \\
\hline 2 & LAZISMU & available & available & available & available \\
\hline 3 & LAZISNU & available & available & available & available \\
\hline 4 & Rumah Zakat & available & available & available & available \\
\hline 5 & Lazis Jateng & available & available & - & available \\
\hline 6 & Aitam & available & available & available & available \\
\hline 7 & Solo Peduli & available & available & available & available \\
\hline
\end{tabular}

The philanthropy institution on Table 4 shows that there is awareness of religious worshippers to overcome the social issues temporarily and the efforts to reduce the poverty which are built in the name of obedience of God's commands and the love to human due to the religion doctrine. Since the development of destitute society is seemed significant with the Regulation Number 23 the Year 2011 about the management which includes planning, collecting, distributing and utilizing of zakat, infak, sedekah and social-religious fund which is conducted in line with the Islamic shari'a with three principal elements; collecting the fund of zakat, distributing the fund of zakat and the organization management of zakat.

\subsection{The Philanthropy Institution as Civil Society}

The culture of philanthropy has close connection with the concept of civil society. This concept is relevant because the philanthropy organization is the part of civil society organization, one of the important elements of which its existence and progress are always related to the existence of civil society. The Social Justice Philanthropy (SJP) which is practiced by philanthropy organizations is the concept, if it is seen from its main character, has the mission of strengthening and empowering society. It is a kind of mission which wants to be realized by civil society. The form of the empowering society and strengthening social can be conducted through the establishment of library which functions as the supporting learning facilities in society[13,14].

With this policy, the organization of civil society which works in the field of Islamic philanthropy found its moment to participate in the philanthropy movement outside the state's framework. The civil society does not only offer the new formulation of civil participation but also the new probabilities of philanthropy movement outside the state like the literacy movement in Islamic school in Demak which was conducted by society 
organization[15]. The movement of voluntary and organized civil organization has an important role in empowering destitute society.

The philanthropy institutions in Boyolali give a positive influence on the development of philanthropy in social service by using the instruments of fund raising, introducing modern methods such as event, email, short text message, internet and etc in raising the fund particularly in the form of zakat, infak and sedekah. The contribution of Islamic philanthropy in Boyolali is not a new thing. NU and Muhammadiyah as the social-religious movement try to solve the social issues faced by the state by establishing charity business such as educational institution, Islamic school (Pesantren), health and social. Muhammadiyah was established from the social base from the middle-class of moslem urban particularly the merchant at the period. They did collectively social activities to give service to destitute native. While NU was established from the rural society that was led by ulama and kyai tried to lift the people from the backwardness through Islamic education by developing the local potency[16].

Therefore, the awareness of religious organization activist in Islamic philanthropy movement has an essential meaning in the efforts to solve the poverty in Boyolali. There is a philanthropy institution which tries to reduce the poverty by distributing half of their wealth routinely to fund the destitute society well in the field of education or economy development by using caritas (direct assistance). There are some philanthropy institutions which try to reduce the poverty by giving the capital assistance. Besides, there is also philanthropy institution which joins to influence the policy through the advocacy by offering the program of poverty reduction. In additional, the philanthropy institution under the society organization tries to solve the poverty by empowering the destitute society through the development of informal education. There are some Islamic schools which conduct empowerment program through increasing the economy of destitute society and there are so many institutions which take part in empowering the destitute society. The empowering activities done by this philanthropy institution are coordinated with the government and the rest of them did the programs by their own initiative which has purpose to reduce the poverty level of society. Retsikas [3] views the philanthropy society in Lazismu shown the complexity of its prosperity's movement. Lazismu is the philanthropy institution owned by Muhammadiyah which the charity business has spread widely to the state. This institution tries to manage the modern philanthropy through Lazismu. Muhammadiyah has experienced many institution's obstacles to manage the central-model of philanthropy. The process of fundraising has run massively in grass root by relying on the track of amil zakat institution owned by the charity business (school, university, hospital, bank, etc) and through the structure of organizers from the level of village to central.

The role of Muhammadiyah through Lazismu as the third sector is the transformation of Muhammadiyah which was established from the society movement by relying on the philanthropy fundraising, and the capacity of service is getting bigger. Muhammadiyah tries to fulfill the needs of fund raising in the sector of education and health through two strategies. The first is the political strategy to approach the government through the connectivity of its cadres to help them get the fundraising from the government. The second is the market strategy. Muhammadiyah changes into half market-oriented by relying on the needs fulfillment of health and education.

\subsection{The Establishment of Philanthropy Culture}

Some studies show that religion has a strong influence towards the increasing of philanthropy culture and religion's involvement in social field. The affiliation of religion 
and religiosity strongly influences on the philanthropy practices. In Indonesia with the Moslem majority, the philanthropy practice is more dominated by religious inspiration compared to the humanity inspiration. The religious inspiration implicates on the form of philanthropy activities with caricative nuance and service. The voluntary practice of giving, serving and associating is to help other in need as the expression of love. Islam as the religion of rahmatan lil'alamin displays itself as philanthropy religion[17]. The form of philanthropy is explored from the religious doctrines sourced from Al-Qur'an and Hadits which are modified with mechanism of ijtihad so the institution of zakat, infak, sedekah and wakaf arise. The purpose is to make the wealth spread to many people not only in rich people.

The Islamic philanthropy can be meant as a charity which is based on the view to promote the social justice and benefits for public society[18]. However, if the charity is closer to the religious doctrine so the practice is more individual because it regards to reward and sin, so the scope of philanthropy is wider because it is closer to the moral philosophy in the social practice. Besides, the charity system also guarantees more on the freedom and only valid to the system of capitalist society which is liberals where the society can respect an individual and uphold highly the human right. On the other hand, people get the freedom to earn wealth because just being rich, people can do the charity which is at the end with charity, people can get into the heaven.

The main basic of Islamic philanthropy is sourced from Al-Qur'an, Surah Al-Ma'un: 17 which one of the signs that someone denies the religion is not donating to the orphan. It means the social concept in religion which then arise Zakat doctrine (takziyah) experienced two stages, the stage of makkiyah (theological) is the stage to clean ourselevs and the stage of maddaniyah is the stage to clean the wealth by giving it to eight asnaf. In the charity position, it can be understood as a philanthropy. Basically, Islamic philanthropy is rich with individual characteristic because it strongly relates to the pray. It shows that vision which was given in the early era of prophet brought the social vision of Al-Qur'an to enforce the justice of social and economy. Not only that, the paragraphs in Madinah emphasizes more on the importance of philanthropy implementation. If it is viewed from its characteristic, there are two kinds of philanthropies, traditional philanthropy and charity-based philanthropy. The traditional philanthropy is charity-based philanthropy. The practice of traditional philanthropy is the form of giving to the social service importance. The direct giving by the giver to the poor is to fulfill their daily needs.

\section{Conclusion}

Theoretically, the state's failure in making the society prosperous encourages the society involvement in collective social action. This social action established various movement to respond the issues of social, economy, and politic. There are three responses of society in viewing the state's limitation. The first, the service-based organization/group is providing assisatance in short period. The second, development-based organization tries to develop the society outside the structure of government. This organization tries to raise the collective involvement of society to join directly solving the social issue in the micro level (individual and community). The third, organization which is oriented to do a collective awareness to demand the structure change of social, economy and politic. The philanthropy institution as a civil society has a role division among the state, market and civil society in realizing the system of prosperity. The three of them have role to support each other in realizing the prosperity. The philanthropy institution as the third sector realizes the social prosperity in the form of social obligation culturally. Buffer zone as the the result 
of the state's failure in realizing social prosperity is needed the initiative from the religious institution as the third sector.

\section{References}

1. S. M. Rigdon, The Culture Facade: Art, Science, and Politics in the Work of Oscar Lewis (Chicago, University of Illinois Press, 1988)

2. S. Daly. Public Manag. Rev 13, 8 (2011).

3. K. Retsikas. Malay World 42, 124 (2014).

4. M. Rein. Challenge 60, 5 (2017).

5. J. Hunsaker and B. Hanzl, Understanding social justice philanthropy (Washington, National Committee for Responsive Philanthropy, 2003)

6. J. Midgley, Social development: the developmental perspective in social welfare (London, Sage Publication, 1995)

7. M. Hill, Social Policy: a comparative analysis (London, Prentice Hall, 1996)

8. G. Helmke and S. Levitsky. Perspect. Polit 2, 4 (2004).

9. M. Q. Patton, Qualitative research \& evaluation methods: integrating theory and practice (California, SAGE Publications, 2015)

10. M. B. Miles, A. M. Huberman, and J. Saldana, Qualitative Data Analysis: A Methods Sourcebook Edition third. Los Angeles: SAGE Publications, 2013.

11. H. R. Bernard, Social research methods: qualitative and quantitative approaches (Los Angeles, SAGE Publications, 2013)

12. M. Horhoruw, T. G. Karippacheril, W. Sutiyono, and T. Thomas. World Bank Publ (2012).

13. P. Suharso, B. Sudardi, S. T. Widodo, and S. K. Habsari. IOP Conf. Ser. Earth Environ. Sci 116 (2018).

14. P. Suharso, B. Sudardi, S. T. Widodo, and S. K. Habsari. E3S Web Conf. SCiFiMaS 47 (2018).

15. P. Suharso and S. Sarbini. E3S Web Conf. SCiFiMaS 47 (2018).

16. G. Barton. Islam Christ. Relations 25, 3 (2014).

17. N. Kholis, S. Sobaya, Y. Andriansyah, and M. Iqbal. J. Ekon. Islam 7, 1 (2014).

18. Z. Abidin. J. Stud. Masy. Islam 15, 2 (2013). 